\title{
COMPUTER ASSISTED INSTRUCTION IN LEARNING SCIENCE CONCEPTS AT EIGHTH STANDARD LEVEL - AN EXPERIMENT
}

\section{Flossie Williams* \& Yatheesh K. Rawgol**}

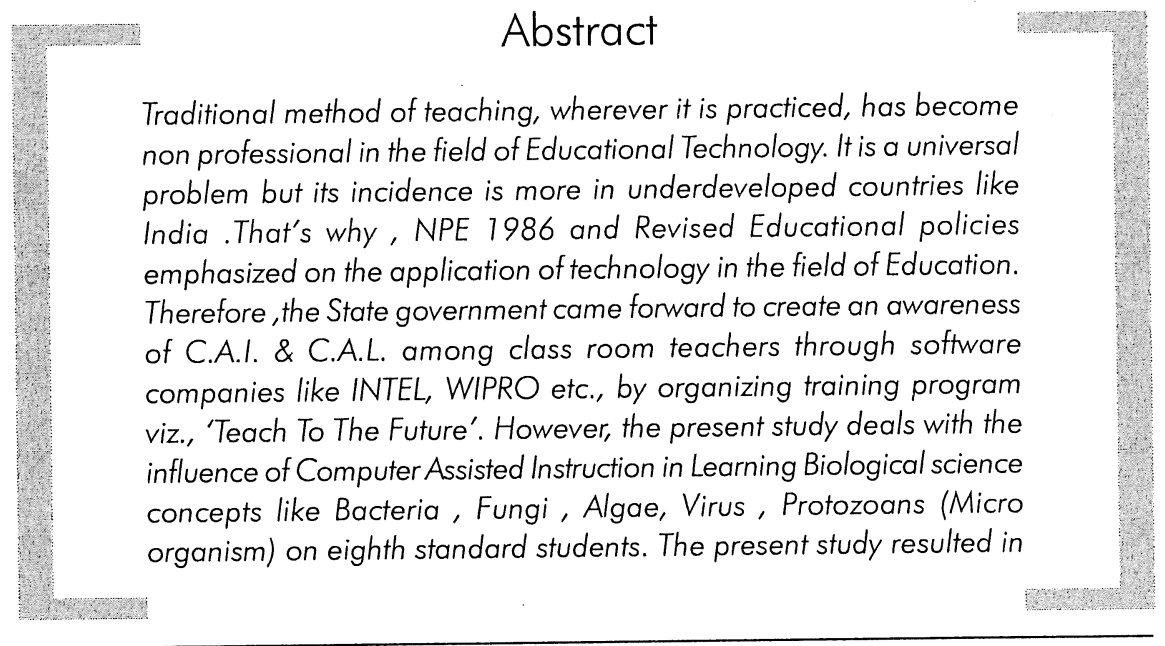

* Frank College of Education, Bangalore -79.

* School of Education, Christ University, Bangalore -29 
the highest performance by the Experimental group in their post test compared to Controlled group. The Experimental group showed remarkable improvement in the number of first classes. The slow learners proved their success by achieving 100\% result. These students remained active through out the sessions in the Experimental group as compared with controlled group. The 't' test was found to be significant. Performance of boys and girls in the post test showed negative correlation, which was perfect.

\section{Introduction}

Education is the torch bearer for the student who is having inquisitive nature. Education facilitates the person to co-operate with the others. It is the fundamental maxim of fostering the progress of the country. It is born within the child, nurtured within the adults, provides occupations for the poor people and status for the higher level community.

Hence, the researcher decided to do some thing new to the nation to foster the quality of Education. The researcher had framed the conceptual aspects for the present study.

\section{Conceptual Frame Work}

\section{Education}

Etymologically, the term 'Education' is believed to have been derived from the Latin word 'Educere' which means 'to bring forth' or 'a propulsion from the internal to external'.

\section{Old Concept}

"Education is something which makes a man self-reliant and selfless" - Rigveda.

"Education is that whose end product is salvation."-Upanishadh

"Education is the realization of the self".- Shankaracharya

\section{Modern Concept}

"Education is the manifestation of divine perfection already existing in man". -Swami Vivekananda 
"Man is neither mere intellect nor the gross animal body nor the heart nor. soul alone. A proper and harmonious combination of the three is required for the making of the whole man and constitutes the economics of education".

- M.K.Gandhi

"Along with the possession of knowledge and efficiency, education should include programmes related to cultural values, community and social responsibilities in order that different scientists and persons getting technical training may be acquainted with their duties and responsibilities. In other words, their concept states, that the process of education is to provide opportunities for the flowering of human personality for manifestation of the qualities that are already present in the child or for drawing out the best in all aspects of human personality. Human soul is a part of that totality which is manifested in God and education is to realize that divine macrocosm in yourself by working for the welfare of all those others who are part of it."

-Dr.Radhakrishnan

\section{Western Old Concept}

"Education is the capacity to feel pleasure and pain at the right moment. It develops in the body and the soul of the pupil all the beauty and all the perfection which he is capable of."

-Plato.

"Education is the creation of the sound mind in a sound body. It develops man's faculty, especially his mind, so that he may be able to enjoy the contemplation of supreme truth, goodness and beauty in which perfect happiness essentially lies".

- Aristotle

\section{Western Modern Concept}

"Education is the process of living through a common reconstruction of experiences. It is the development of all capacities in the individual which will enable him to control his environment and fulfill his possibilities".

- John Dewey.

"Education is a natural , harmonious and progressive development of man's innate power".

-Pestalozzi

"Life is education and education is life".- Lodge

"Education may be defined as a systematic process of determining the extent in which instructional objectives are achieved by pupils".

\section{Technology}

"It is a science of techniques and methods of doing or getting things done, related to any art, science or a particular profession" 
"Technology is the application of science to the needs of an individual and the
society".

"Technology is a scientific way of developing new techniques and a systematic way of evolving and applying techniques".

"Technology is the technical means people use to improve their surroundings and also the knowledge of using tools and machines to do tasks efficiently."

\section{Educational Technology}

"Educational technology provides the means to reach large numbers in remote and in accessible areas, remove disparity in educational facilities available to the disadvantages and provide individualized instruction to learners conviently suited to their needs and pace of learning." -NPE 1986.

"Educational technology as a complex, integrated process involving people, procedure, ideas, devices and organization, for analyzing problems and devising, implementing, evaluating and managing solutions to those problems involved in all aspects of human learning. The process for analyzing problems and devising, implementing and evaluating solutions are identified by the educational development functions of research, theory, design, production evaluation, selection, logistics, utilization and dissemination. The processes are directed by educational management". A.E.C.T.(Association for Education Communications Technology).

\section{Computer Assisted Instruction}

Computer Assisted Instruction is an interactive instructional method that uses a computer to present material, track, learning and direct the user to additional material which meets the students' need.

Computer Assisted Instruction is a method of instruction in which there is a purposeful interaction between a learner and computer device (having useful instructional material as software) for helping the individual learner to achieve the desired instructional objectives with his own pace and abilities at his command.

Computer Assisted Instruction can be defined as "Use of computer to assist in the presentation of instructional materials to a student, to monitor learning progress or to select additional instructional material in accordance with the needs of individual learners."

\section{Programmed Instruction}

"Programmed instruction is the process of arranging the material to be learned into a series of sequential steps, usually it moves the students from a familiar 
background into a complex and new set of concept, principles and understanding."

- Smith \& Moore

"Programmed instruction is a method of instruction in which the information to be taught is broken into small units which are to be presented to the student in a carefully planned sequence. Each frame contains not only information but is also terminated with a question."

-Michael J. Apter

\section{Secondary Education}

"Secondary education is a period of education which follows directly after primary education (such as intermediate school or elementary school) and which may be followed by tertiary or 'post-secondary education'. Secondary schools is official term for what was formerly known as 'High schools'. In other parts of the English speaking world, secondary school is often used synonymously with secondary education".

"Usually schooling for children between the ages of eleven and eighteen."

"Secondary education consists of the second years of the formal education that occur during adolescence".

\section{Science}

"The Science is a branch of systematized knowledge as an object of study. It is a co-ordinate knowledge of operation of general laws".

"The ordered arrangement of ascertained knowledge, including the methods by which such knowledge is extended and the criteria by which its truth is tested".

\section{Concept}

"A concept is the basic unit of all types of learning and relates to a class of objects or ideas which have one more common characteristics".

"Concept is something conceived in the mind".

"Concept is a generalized idea covering many similar things derived from study of particular instances".

\section{Concept Formation}

"The process from early life on by which the individual learns to classify the aspects of his world. Much of such learning is verbal and one of the main problems seem to be over generalization".

"Concept formation is the process of developing concept".

"Concept formation is the process of development of concepts involving four elements such as experiences, abstraction, generalization and analysis". 


\section{Theoretical Background of the Study}

After independence, the National educational system was designed in 1968. Due to many reasons, our central government could not implement the recommendations of neither Kothari commission nor National education policy 1968. Thus, the most of recommendations were cornered and neglected. The 1985, former prime minister Rajeev Gandhi's government reviewed the 1968 National Education Policy. He ordered the educational departments to reframe with all sorts of new ideas in the name of New Policy of Education. The government invited the Educationists, Thinkers and Co-ordinators from all over India. They associated the various problems of our country like lack of basic amenities of our educational system, economical problems, poor administrative plan etc,. They published a book entitled " Challenges of Education ". They held many discussions at national level and finally came up with "1986-New Policy of Education".

Later the Ramamurthy commission 1990 and Janardhana Reddy commission 1992 analysed the implementation of 1986 NPE and revised the same in 1992. They ordered the state government to follow the NPE - 1992 rules and regulations. They also stressed on the point; the political government do not have the right to twist or change the educational system however they want. They should approach the parliament to take any sorts of decision pertaining to educational system.

According to National Policy Education 1992-

* Free and compulsory education for all children of 6-14 years. Hence, the government has initiated Primary school in all the villages

* Providing quality education.

- Nurture the abilities and creativities among children.

Our nation has been approaching the scientific and technological field to achieve the progress of educational field. There were many research works being done to improve the quality of our education. It is looking for the reliable techniques to nurture the potentialities of children.

The year of 1966 was the mile stone of the Indian history because, the educational system was scrutinized by the member of eastern and western countries. This commission had written the suggestions which are acceptable in nature and also given the secret information to the educational system. That is,

* The destiny of our nation is being moulded in the class room.

* The entire world is depend upon the science and technology to bring goodness and to provide protection to the Indian citizen. If you would like to achieve the same, the government has to implement the programmes with all confident. 
This was mentioned in 1966 education commission. So the aims of education system should be achieved by providing learning experiences through the curriculum. The curriculum 2000 has been structured based on philosophical, sociological, psychological and technological point of view. This will facilitate the methodologists to achieve the impossible aspects as a possible one. The teaching learning materials would be prepared based on technologies to make it more effective. For example POA (Programme of action) POA came forward in 1992 to establish the education based programmes. The science topics can be taught through Computer assisted instruction which is a boon to the Science teacher. Therefore, a systematic teaching, micro teaching, interaction, analysis and CAl will be germinated into a gigantic tree.

The computer made all impossible subject matter possible. All of us should accept and appreciate the nature of computer technology that is why the ninth five yearly plan had emphasized on computer based teaching learning process. There were many technological companies which came forward to adopt the schools to give proper education. New policy of education has designed the articles and provision with regards to the above. Our philosophers and vedantics scholars have described the $21^{\text {st }}$ century as the "Kali yug" where as the technologists called it as "Computer yug" or "Computer Era". The children have been learning many aspects informally with high speed. Therefore they may feel the classes are inferior. Thus the teacher has to realize the present situation and recent developments in the Educational field. Therefore he has to try to bring out the technological atmosphere in the classroom teaching by using Computer assisted instruction. In the light of this, the researcher made an attempt to improve the quality of education by taking the problem for his study i.e "Computer Assisted Instruction in learning science concepts at $8^{\text {th }}$ std level-an experiment".

\section{Justification of the Study}

According to our educationists' thoughts, human beings are the main sources for the progress of a country. Hence, the quality of education should be given to all children right from the beginning by means of love and affection, perfect ness and with carefulness. Such a child would find the path for his life based on scientific principles, philosophical thoughts, morality, punctuality etc. Our educational system should provide the same for the child. Science is not a bundle of information, facts, formulae, theories or exhibition of model specimens. It is the way of finding an answer for the questions in a systematic way. It designs the style of living. The present day teachers are teaching their lessons in a monotonous way like an eyes in the dead body. If the students felt the same it is not an exaggeration. If the teachers wanted to disprove the same, they have to work hard and approach the 
scientific technology. The Karnataka government come forward to implement the information technology in our educational system. It is the pioneer in this attempt.

The Chancellor of Karnataka government dated 15-3 2000 had proposed the implementation of information technology comprehensively and effectively.

"Our government have decided to use the information technology to improve the quality of our education. When others are talking about the information technology, we are also paying our attention towards the same. Hence, we are going to start Computer Assisted Instruction in thousand schools".

By keeping all these ideas in the mind the government made an attempt to improve the rural students by implementing "Mahithi Sindu" programme in a large scale. It has given a tender for INTEL COMPANY to facilitate these schools. The same company has been training many teachers. The researcher also has been trained by the same company. He has prepared the learning materials with the help of learnt knowledge and test the same in school condition. Thus, the researcher need to study the influence of computer assisted instruction on secondary school children. He has tried to bring out the necessary and innovative changes in the class room teachings and also to cater the present trend of children to adjust for the computerized society. The Researcher wished to know about;

- a cross section of the studies throws significant light on various factors related to the Computer Assisted Instruction.

- the study of related literature studies helps in identifying the various trends that have emerged in similar studies.

- the recent developments in the computer assisted instructional field of education.

- the significant works of an experimental method.

- the ways of applying the research findings to educational practices in science class room teaching.

The review of related studies were done at two different levels viz., India and foreign. The emphasis so far has been on traditional method of teaching but, the teaching -learning process which is the central problem of education has been neglected With the practical and methodological difficulties involved in the study of educational processes in natural situations being increasingly overcome in future, the neglected areas have received more attention and emphatically analysis of the learning instructional process has the prospect of becoming an important field of research in India and even at foreign level. These processes will also include emerging computer assisted instructional method in the educational field.

Based on the summarization of the related studies the researcher has been realized the importance of CAl in the educational system. Therefore, the researcher had 
chosen the Experimental method to find the solution for the present problem in Biological science discipline.

\title{
Methodology: The Problem of The study: "Computer Assisted
}

\author{
Instruction in Learning Science Concepts at $8^{\text {th }}$ Standard level - An experiment"
}

Operational Definitions : (1) Computer Assisted Instruction: "The desired learning materials are prepared based on syllabus for the specific group of students in a specific to bring out desirable change." Computer assisted instruction means to create like science classroom situation by using Microsoft power point slides based on the standard syllabus. (2) Science concepts: The science concepts are the generalized ideas of science

Aims and Objectives: The aim of present research was to study the computer assisted instruction in learning science concepts at $8^{\text {th }}$ standard level in relation to academic achievements, manipulating abilities, self pacing etc. The aim covers the relationships or associations among these variables and the effects of CAl on academic achievements of $8^{\text {th }}$ standard students. The afore mentioned aim was further specified in the form of following major objectives:

- To find out the effectiveness of C.A.I in teaching science subjects.

- To find out the mean score difference between pre test and post test performance of controlled and experimental groups.

* To find out the mean score between the post tests performance of controlled and experimental groups.

- To discuss the implications arising out of the findings in the present study for efficient and appropriate use of C.A.l in teaching concept at secondary school level.

Hypotheses: The hypotheses are tentative, but simple explanation is to be subsequently verified, conformed or tested for validity. Hypothesis can provide a definite point or sharpness for the research besides offering a clear direction, rigour and concreteness for the enquiry and thereby, preventing indiscriminate search and gathering of irrelevant data. Further, hypotheses are governed by the boundaries offered by the researcher in his aim and objectives of the study.

For the purpose of present study the researcher framed the following hypotheses.

(1) There will be no significant difference between the pretest and post test performance of Controlled and Experimental groups. 
(2) There will be no significant difference between the post tests performance of Controlled and Experimental groups.

Sampling Design: Population: The population comprises eighty seven students belonging to eighth standard of a private school in Bangalore city.

Sample: The sample was drawn by conducting pre pretest on $8^{\text {th }}$ students. The sample comprised 80 students of the $8^{\text {th }}$ standard of a well reputed school. Later 40 students were distributed to each group equally based on their achievements in the Pre -pre -test, which comprises both boys and girls.

\section{TEST NO.1 \\ SUBJECT : BIOLOGICAL SCIENCE}

NAME OF THE SCHOOL :

NAME OF THE STUDENT :

STANDARD

SECTION

REGISTER NUMBER

INSTRUCTIONS: 1 Read the questions properly.

2. Choose the correct answer from the answer stalk and write their alphabet in the given bracket.

3. Use blue or black pen to write.

4. Don't write unnecessary wordings on the given paper.

1. The taxonomy deals with

(a) grouping, identifying and naming of organisms.

(b) grouping of organisms

(c) naming of organisms

(d) identifying the organisms

2 is associated with the synthesis of protein.
(a) Lysosome
(b) Ribosome
(c) Endoplasmic reticulum
(d) Golgi complex

3. The organ concerned with secretary function of cell is
(a) endoplasnic reticulum
(b) Golgi complex
(c) mitochondria
(d) ribosome 
4. The term cell was coined by
(a) Leeuwen Hoek
(b) Robert Hook
(c) Robert Brown
(d) Aristotle

5. Lysosomes are also called
(a) Suicide bags
(b) Pockets of enzymes
(c) Powerhouse
(d) Protein factories

\section{PART "B"}

\section{Write answers for the following questions}

6. Draw a neat labeled diagram of Bacteria.

7. What are the major contributions of Robert Koch?

8. List out the uses of algae.

\section{Write the answers for the given questions in 8 to 10 sentences.}

9. Explain the mode of transmission of malaria.

10. What are the symptoms and preventive measures of foot and mouth disease.

PART "A": 1.a; 2.b; 3.b; 4.a; 5.a

\section{TEST NO.1}

\section{MODEL ANSWER PAPER}

PART "B" :

26. ( $11 \backslash 2$ for diagram $+11 \backslash 2$ for labelling )

27. The major contributions of Robert Koch are as follows: (any3) $(1+1+1)$

- He was the first person who identified the anthrax causing bacteria in animals and introduced the precautionary measures

- He was identified the cause of tuberculosis and who got the noble prize in 1905.

- He introduced the bacterial culture in agar and gelatin media.

- He showed the steps to determine the germs causes a particular disease.

28. Algae are used for different purposes: (any3)

- It produces organic matter though photosynthesis which in turn provides food to aquatic animals.

- The extracts of algae are used in many commercial products.

- Agar and argenic acid are used in the preparation of medicines, food and cosmetics

- Red algae are used as a source of food in China and Japan 
1. Mode of transmission of Malaria: It is caused by plasmodium vivax. It spreads through female Anapheles mosquitoes. IPlasmodium takes an entry into the human blood stream through the mosquito bite of anafeles. In the stomuch of the mosquito, plasmodiva multiply. If such a mosquito bites a healty person, they multyply and reach liver. Then they attack red blood cells. In the blood multiplication repeat for every 48 hours or 72 hours.

30. ( 3 for any symptoms and 2 for precautions)

The symptoms and preventive measures of foot and mouth disease.

SYMPTOMS;

1. Virus affects the split hoofs

2. Blister appears in the clefts of their hooves .

3. Blisters are also seen on the tongue.

4. They unable to chew cuds .

5. Secrete saliva profusely.

PRECAUTIONS:

1. Vaccinate the other animals.

2. Don't drink the milk taken from the infected animals .

3. Keep their surroundings clean.

4. Burn the infected animal after their death.

\section{Variables}

The changing factors in the experimentation are called variables. Such as independent, dependant and extraneous variables .

Independent variables: computer assisted instruction

Dependant variables: achievement

Extraneous variables : intelligence.

Intelligence may affect the achievement in tests since it is not related to the purpose of the study under taken by the researcher. Whatever effect is noticed on dependant variable as a result of extraneous variables is technically described as an " Experimental error".

\section{Instrumentation}

Instrumentation is the process of structuring and validating the research tool.

In any type of educational research data is required because answer to research questions are sought on the basis of empirical data. Data is gathered using readily available tools or those which are modified or developed by the researcher. In the present study, the questionnaires were prepared by the researcher. It consists of 150 questions and employed the test in terms of Pre-test No. 2. was employed. Later, 
questions were reshuffled and the test was administered to the test to the same sample in terms of Post- test No. 3. From this, ten questions were randomly selected. The final test was as shown below;

TEST NO.2 / 3

NAME OF THE SCHOOL :

SUBJECT : BIOLOGICAL SCIENCE

NAME OF THE STUDENT :

STANDARD

SECTION

REGISTER NUMBER

INSTRUCTIONS: 1 Read the questions properly.

2. Choose the correct answer from the answer stalk and write their alphabet in the given bracket.

3. Use blue or black pen to write.

4. Don't write unnecessary wordings on the given paper.

1. Mushrooms are the best examples of
(a) Autotrophs ]
(b) Heterophytes
(c) Saprophytes]
(d) Epiphytes

2. Virus included under the
(a) Monera
(b) Protista
(c) Fungi
(d) None of these

3. The virus becomes living thing when it is
(a) Inside the rock
(b) Inside the water
(c) Inside the soil
(d) Inside the animals and plants

4. The virus becomes non- living thing when it is
(a) Inside the animals and plants
(b) outside the animals and plants
(c) Inside the water
(d) outside the water

5. The kingdom animalia includes all
(a) Unicellular
(b) Multicellular
(c) Both (a) \& (b)
(d) None of these 
6.

(a) Pathology

(b) Micro logy

(c) Entomology

(d) Micro-biology

7. The micro-biology is correlated with

(a) Biotechnology

(b) Tissue culture

(c) Biochemistry

(d) All the above

8. is the pioneer contributor of microbiology.
(a) Louis Pasteur
(b) Joseph lister
(c) Arayabhata
(d) None of these

9 Lovis Pasteur was belongs to
(a) British
(b) French
(c) Greek
(d) Dutch

10. Pasteurization is the technique of killing microbes by applying heat at Celsius.
(a) $40^{\circ}-45^{\circ} \mathrm{C}$
(b) $30^{\circ}-40^{\circ} \mathrm{C}$
(c) $50^{\circ}-60^{\circ} \mathrm{C}$
(d) $60^{\circ}-65^{\circ} \mathrm{C}$

\section{MODEL ANSWERS}

$1 b ; 2 c ; 3 a ; 4 d ; 5 b ; 6 b ; 7 c ; 8 d ; 9 a ; 10 c$.

\section{Design of the Experiment}

The present problem was carefully selected by the researcher after knowing the felt need for its study. It was approved by the Department of Education, MKU. and then researcher planned to design the experiment .

The design of the experiment was planned under the following steps;

Step 1 . Selection of the population and topic

Step 2. Formation of the samples

Step 3. Implementation 


\section{Validity of the Research Design}

Research design is the blue print of the procedures to be followed while conducting the experiment. Any experiment to be of advantage should be valid before administering to the large sample. Internal validity of the tool was identified by considering the following factors Maturation, History and Testing of the sample

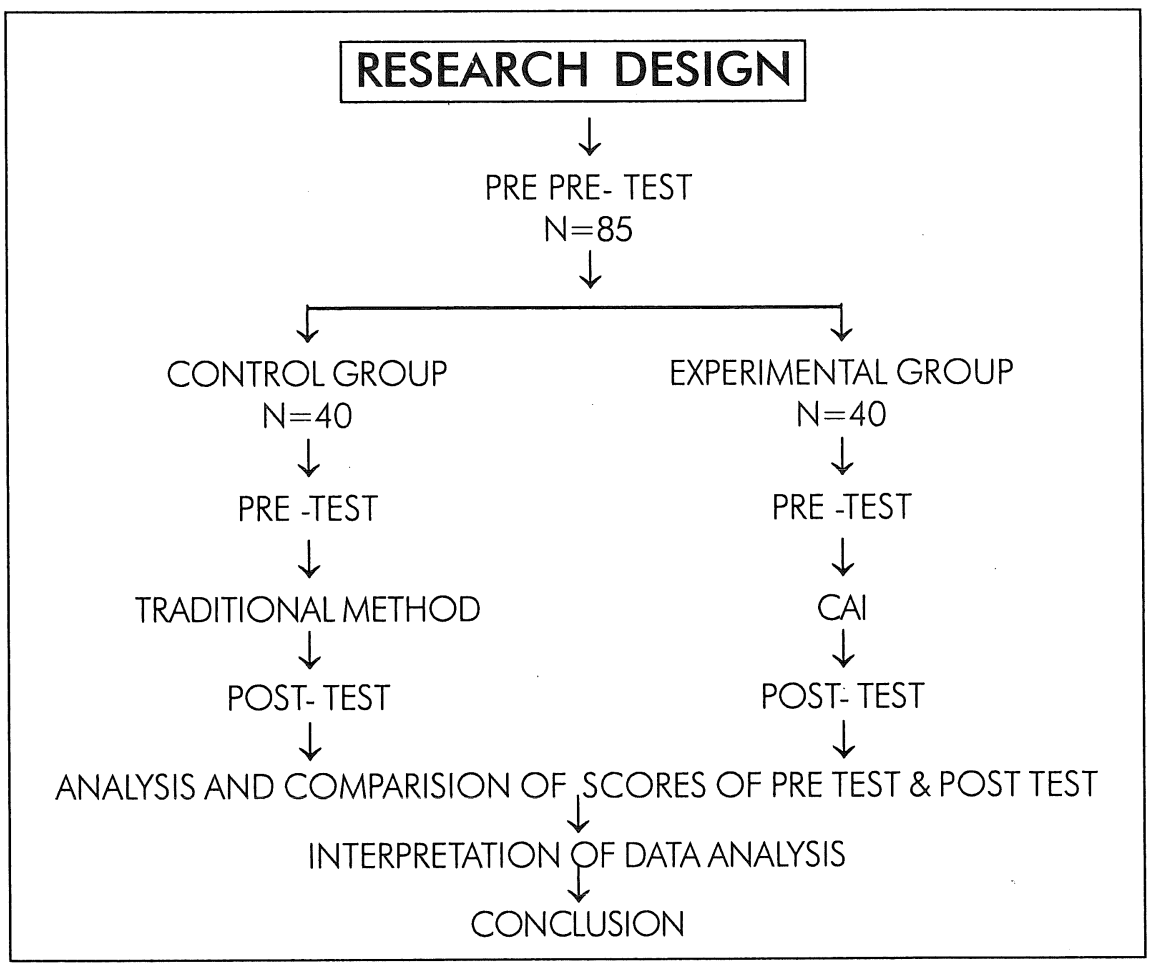

\section{Statistical Techniques}

The following techniques were used in the present study;

1.Mean 2. Standard deviation 3. 't' Test 4. Correlation

\section{Differntial Studies :}

\section{Graphical Representation of Data}

Graphs 1 . and 2. indicates that the large number of students' scores were clustered towards the left hand side in Controlled group (C). Where as, students' score of 
Table A

\begin{tabular}{|c|c|c|c|}
\hline SL. No. & Method & N & $\begin{array}{c}\text { Co-efficient of } \\
\text { reliability }\end{array}$ \\
\hline 1 & Test-Retest & 150 & 0.033 \\
\hline
\end{tabular}

Table B

\begin{tabular}{|c|c|c|c|}
\hline SL. No. & Test & N & Co-efficient of \\
\hline 1 & Pre pre- test & 30 & 0.724 \\
\hline 2 & Pre -test \& post -test & 150 & 0.78 \\
\hline
\end{tabular}

Experimental group(E) towards right hand side. It shows the better performance of ' $E$ ' group as compared with then ' $C$ ' group.

\section{Interpretation Phase}

Table 1. MAJOR HYPOTHESES:

Table 1. Shows difference between the $C^{\prime} \&$ ' $E$ ' Groups in Various Tests.

\begin{tabular}{|c|c|c|c|c|c|c|c|c|}
\hline \multirow{2}{*}{ Groups } & \multicolumn{5}{|c|}{ Pre Test } & \multicolumn{3}{|c|}{ Post Test } \\
\hline & $\mathrm{N}$ & $x$ & $\sigma$ & $\mathrm{T}$ & $\mathrm{N}$ & $x$ & $\sigma$ & $T$ \\
\hline Controlled (C) & 40 & 3.6 & 4.0546 & 0.2495 & 40 & 58.35 & 27.9748 & 9.0288 \\
\hline Experimental $(E)$ & 40 & 3.35 & 4.8718 & in $S$. & 40 & 111.25 & 24.301 & $\begin{array}{r}\text { s at } 0.01 \\
\text { Level }\end{array}$ \\
\hline
\end{tabular}

Table 2. Shows the difference within the Groups in its Pre and Post Tests.

\begin{tabular}{|c|c|c|c|c|c|c|c|c|}
\hline \multirow{2}{*}{ Tests } & \multicolumn{5}{|c|}{ Controlled Group (C) } & \multicolumn{3}{|c|}{ Experimental Group (E) } \\
\hline & $\mathrm{N}$ & $x$ & $\sigma$ & $\mathrm{T}$ & $\mathrm{N}$ & $x$ & $\sigma$ & $\mathrm{T}$ \\
\hline Pre Test & 40 & 3.6 & 4.0546 & 0.2495 & 40 & 3.35 & 27.9748 & 9.0288 \\
\hline Post Test & 40 & 58.35 & 4.8718 & in $S$. & 40 & 111.25 & 24.301 & $\begin{array}{r}s \text { at } 0.01 \\
\text { Level }\end{array}$ \\
\hline
\end{tabular}

Table 3. Shows the Performance of ' $C$ ' \& ' $E$ ' Groups in Post Test.

\begin{tabular}{|l|r|r|r|r|}
\hline \multirow{2}{*}{ Group } & \multicolumn{4}{|c|}{ Post Test } \\
\cline { 2 - 5 } & $\mathrm{N}$ & $\mathrm{X}$ & \multicolumn{1}{c|}{$\sigma$} & \multicolumn{1}{c|}{$\boldsymbol{9}$} \\
\hline Controlled (C) & 40 & 58.35 & 27.9748 & $\begin{array}{r}9.0288 \\
\text { Experimental (E) }\end{array}$ \\
& 40 & 111.25 & 24.301 & $\begin{array}{r}\text { S. at } 0.01 \\
\text { Levels }\end{array}$ \\
\hline
\end{tabular}


Table 4. Shows the " $T$ " Values at Different Levels of Significance at Df. 38.

\begin{tabular}{|l|c|c|c|}
\hline Significance Level & 0.05 & 0.01 & 0.001 \\
\hline "T" Value & 2.21 & 2.704 & 3.551 \\
\hline
\end{tabular}

"There are no significant differences between the pretest and post performance of Controlled and Experimental groups".

\section{Frequency Table For Both ' $\mathrm{C}$ ' And ' $\mathrm{E}$ ' Groups}

\begin{tabular}{|l|c|c|}
\hline \multirow{2}{*}{ Class Intervals } & \multicolumn{2}{|c|}{ Frequencies } \\
\cline { 2 - 3 } & Controlled Group(c ) & Experimental Group (E) \\
\hline $126-150$ & 4 & 9 \\
$101-125$ & 3 & 22 \\
$76-100$ & 20 & 3 \\
$51-75$ & 7 & 6 \\
$26-50$ & 6 & \\
$0-25$ & $\mathrm{~N}=40$ & $\mathrm{~N}=40$ \\
\hline
\end{tabular}
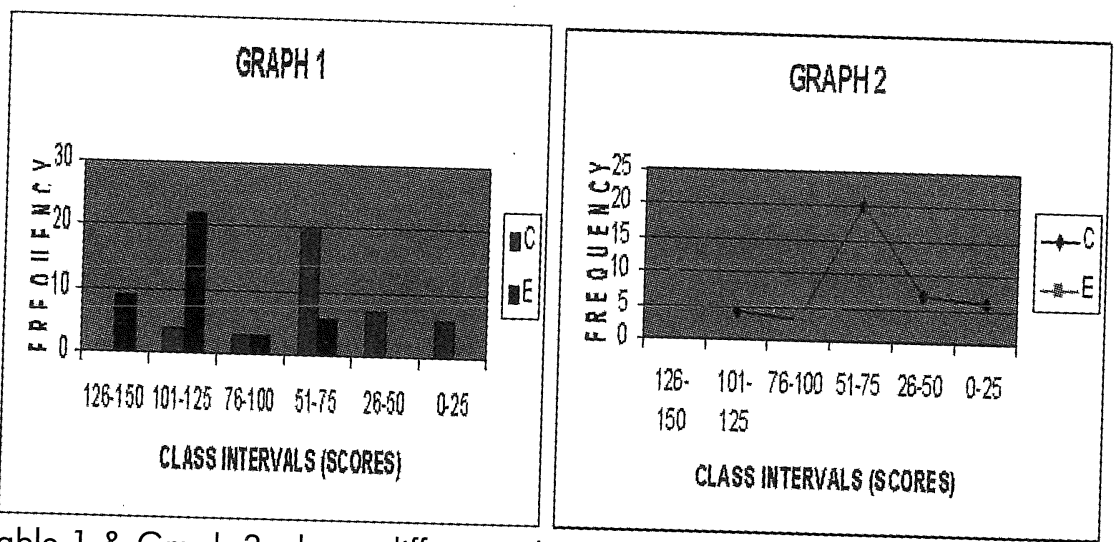

Table 1 \& Graph 3. shows difference between the ' $C$ ' \& ' $E^{\prime}$ groups in various tests. 


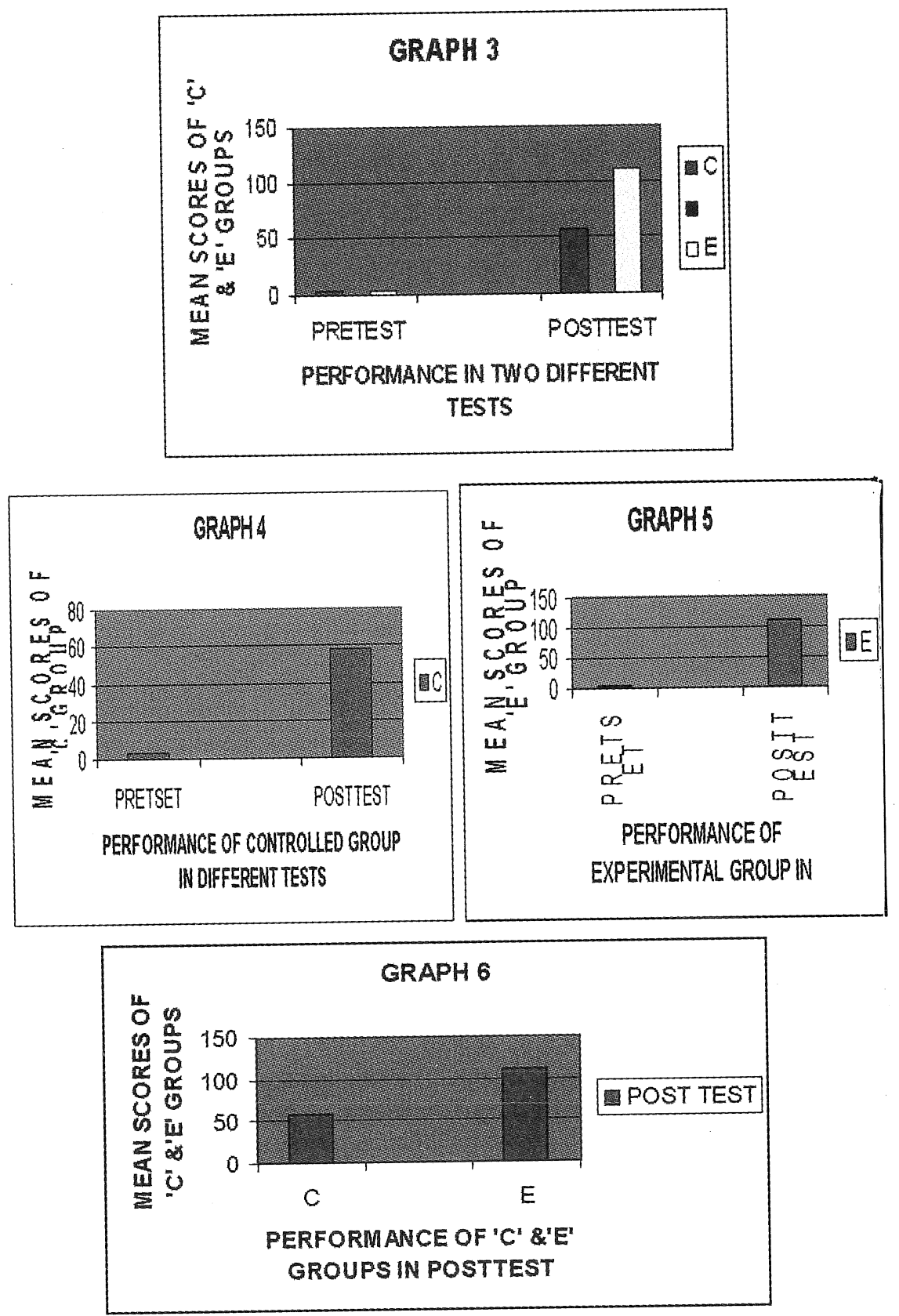


It could be seen from the Table No. 1 \& Graph 3 that mean of Experimental group is less in pre-test when compared to the Controlled group. In the post-test, mean value of Experimental group is 111.225 more than the Controlled group ie.58.35. The actual differences are 0.025 in pretest and 52.9 in post test. Hence, the Experimental group has given better performance than the controlled group in post -test.

As the obtained " $t$ ' value is 0.2495 in pre-test, it is in significant at all the levels. In post-test 9.02884 and it is significant at 0.01 level. The null hypothesis is rejected and the alternative hypothesis is accepted. Hence, there is a significant difference between the performance of pre-test and post-test of Controlled and Experimental groups.

Incidentally, " $t$ " value at 0.01 level of significance for 38 degree freedom is 2.704 The obtained " $t$ " value is 9.02884 . So, the difference happens to be significant at even 0.01 level also. This gives a greater assurance for rejection of the null hypothesis.

\section{TABLE.2}

Table 2 \& Graphs 3 \&4 show the difference within the groups in its pre and post tests.

It could be seen from the Table 2 \& Graphs 3 \&4 the mean of controlled group is less in pre-test as compared to post-test. The consistency is more in pretest than in post test performance of the Controlled group. The Experimental group is facing the same condition in their performance. The values are higher than that of the other.

As the obtained ' $t$ ' test values of both the groups shows that there is a significant differences in their performance. The obtained value 12.249 is significant at 0.05 levels for controlled group. Whereas, the obtained value of experimental group is 9.028 which is significant at 0.01 levels. When we compare both ' $t$ " values, it indicates that the performance of experimental group is at superior level.

The result shows that, there is a tremendous influence of treatment given to the experimental group during the experimentation i.e. COMPUTER ASSISTED INSTRUCTION. Hence, there is a significant difference in their performances between two groups.

TABLE. 3

MAJOR HYPOTHESIS

"There is no significant difference between the post test performance of controlled and experimental groups". 
Table No. 3 \& Graph 6 shows difference in the performance of ' $C$ ' $\&^{\prime} E^{\prime}$ groups in post -test.

It could be seen from Table 3 that mean of controlled group is less than the mean value of experimental group ie.58.35 and 111.25 respectively. That indicates the performance of the experimental group has achieved high level in their scoring in post-test.

The standard deviation also says that, the Experimental group has got more consistency than the controlled group in the performance of post-test.

The obtained " $t$ " value is 9.02884 of both the groups. The value is significant at 0.01 levels. This gives greater assurance for rejection of null hypothesis. Hence, the null hypothesis is rejected and the alternative hypothesis is accepted. The result shows that, there is a significant difference in the performance of experimental and controlled group in the post test.

\section{Correlational Studies}

\section{Interpretation}

Table No5. Shows the co-efficiency of correlation between the pretest and post test performance of experimental group.

1] If the relative ranking level of each student in a sample is exactly in the reverse order in one test as in the other, the relationship is perfect but negative and the co-efficient of correlation is - 1.00.

There is no such relationship between the performances of girls in pretest and post test. This shows that some factor has influenced their performance at post- test i.e CAI.

Table 5. Shows the Correlation between the Boys and Girls.

\begin{tabular}{|c|c|c|c|}
\hline Correlation & Girls & Boys & Total students \\
\hline Pretest and post test & -1.00 & -1.6956 & -2.5583 \\
\hline
\end{tabular}

2] A few students secured the same ranking level and most of them secured different ranking level that deviates from the previous test. The co-efficient of correlation of boys is -1.6956 . and it denotes that the relationship of boys and girls was found to be negative. It reveals that CAl played an importance in promoting the performance level of the boys in post- test.

3] If the relative position of each student in a sample is in reverse order in one test as in the other, then only few students had retained the same position and 
the relationship is perfect but negative and the coefficient of correlation is -2.5583 . It shows that the CAl had promoted the students to show good performance in the post- test.

\section{Findings of the Study}

- There is a significant difference between the performance of pretest and posttest of Controlled and Experimental groups. - There is a tremendous influence of treatment given to the experimental group during the experimentation i.e. COMPUTER ASSISTTED INSTRUCTION. Hence, there is a significant difference in their performances between two groups. - There is a significant difference in the performance of experimental and controlled group in the post test. • The correlation between the test performance of boys and girls is perfect but negative. - The Computer assisted instruction has a significant effect on the learning of science concepts at eighth standard level in the post test of the Experimental group. - The Experimental group showed remarkable improvement in the number of first classes and pass class were $100 \%$.

\section{Limitations of the Study}

1. The sample is heterogeneous. Thus the group has to be divided into sub groups, according to their levels. But this tool was not prepared based on their levels hence, it is limited to cater to one or two levels only.

2. The SES (socio-economic status) of the learner was not considered in this study.

3. The duration of this Experiment was ten days only.

4. The general mental ability of the sample was neglected hence the researcher did not administer any test like R.S.S.B General mental ability test to determine their general intelligence.

5. This study was made on only eighth standard students.

6. This study was made only in a city school.

7. The sample selected was small in number ie. 40 . So, its findings may not be considered as a representative of that age group.

8. The competencies of the teachers regarding CAl was not taken into the consideration

\section{Suggestions for further Study}

From the experiences during the study and findings made, the researcher wishes to make the following suggestions for further study. 
- This study was made with many limitation like subject matter, topic, sample, class, place, medium of instruction etching further study, these variables may be introduced to find the influence of CAI

* This approach may be tried in rural areas.

- This approach may be tested for effectiveness in other fields of schooling such as Primary, Pre University, Vocational areas.

- This approach may be tried in community such as mass media for population education.

- Follow up work of finding out whether the CAl method has enabled the children to improve their achievement in their higher classes can be taken up.

* Standardized achievement tests can be used for evaluation purposes.

- The study of implementation of computer assisted instruction in private and government schools can be taken as a survey project work.

\section{Conclusion}

This study has made the researcher to learn the techniques of research in the field of education. The findings of this study has influenced the investigator to take up further research work with different variables and topics. On the whole the investigator wishes to express that the pains taken for the present study are worth and rewarding.

\section{Bibliography}

\section{(A) Books}

1. Dr. Chaube S.P. and Dr. Akilesh chaube 'Philosophical and sociological foundations of education'. Vinod Pustak Mandir Co. 2006

2. Collocotto T.C and Dobson "Dictionary of science and technology". Allied Publications Private Limited. 1984.

3. Gibbons Andrew. S 'Computer Based Instruction: Design and Development' Engle Wood Cliffs. 1980.

4. Henry E. Garrett, "Statistics in Psychology and Education" David Mekay Co.,Inc. New York. 1973.

5. John w. Best-'Research in education' Vikas Publications. 1977.

6. John Dececco \&William 'The Psychology of learning and Insruction' New yark1970.

7. Dr..Kulashreshta S.P'Teaching of Biology' Surya Publication.2006. 
8. Kothari C.R. "RESEARCH METHODOLOGY-Methods \& Techniques", New Dehli Publications, 2001

9. Mangal.S.K 'Foundation of Educational technology' Tandon Publications Pvt Ltd.2004.

10. Dr. Rainu Gupta 'Education in Emerging Indian Society'Jagadamba Publishing Co. 2005.

11. Roblyer M.D -Jack Edwards "Integrating Educational Technology into Teaching". Printice Hall International 2000.

12. B.R.Satija B.R. "Trends in Education". Anmol publications Pvt. Ltd.2003

13. Dr. (Fr) Thomas chathamparampil "Organizational commitment of teachers of Higher Education". Christ college publications. 2004,

14. Vanaja.M "Educational Technology". Neel Kamal Publications Pvt.Ltd. 2006.

(B) Periodicals

1. DSERT "SHIKSHANA VARTHE". 2001.

(C) Research Abstract

1. Dr.Buch. M.B"Fifth survey of Educational Research" New Dehli, NCERT, 2001

2. Dr.Buch.M.B "Fourth Survey Of Educational Research" Vol. 11 ,Newdehli,Ncent, 1983-88

3. "Dissertation Abstracts International" vol.56 No.6 Oct.1995,A Bell of How well co. Michigan, USA.

4. "Dissertation Abstracts International" vol.50 No. 11, May 1990, A Bell of How well co. Michigan, USA.

5. "Dissertation Abstracts International" vol 50 No.3, September 1989, A Bell of How well co. Michigan, USA.

6. "Dissertation Abstracts International" vol.50 No. 11, May 1990, A Bell of How well co. Michigan, USA.

7. "Dissertation Abstracts International" vol.56 No.5, November 1995, A Bell of How well co. Michigan, USA.

(D) Website

1. www.google.com/educational technology/ National Academy of engineering.2007

www.goole.com/images 